\title{
The Frey Effect of Microwave Sonic Weapons
}

\author{
Robert Skopec* \\ Researcher-Analyst, Dubnik, Slovakia
}

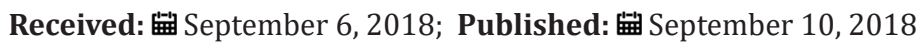

*Corresponding author: Robert Skopec, Researcher Analyst, Dubnik, Slovakia

\begin{abstract}
State Department evacuates a number of Americans from the U.S. consulate in Guangzhou, China after they experienced unexplained health issues. A group of U.S. diplomats stationed in China have been brought back to the states after being inflicted by a mystery illness that reportedly resembles the brain injuries previously suffered by staff in Cuba. Heather Nauert, a State Department spokeswoman, said in a statement that the individuals from the U.S. office in Guangzhou were returned home for further evaluation. It was unclear if there was any connection to last year's situation in Cuba where 24 US government employees experienced a range of ailments after hearing an unusual sound.
\end{abstract}

Keywords: The Frey Effect; The Acoustic Effect of Microwaves; The Sonic Delusions; Bio-Acoustic Deterrents; Sonic Weapons; Carcinogenesis; Loss of Hearing; Balance; Brain Injuries; Nausea; Headaches; Ear-Ringing; State Department; The U.S. Consulate in Guangzhou; China; Havana-Case; Cuba; Secretary of State Mike Pompeo

\section{Introduction}

The New York Times reported that at least two employees removed from China experienced unusual noises while there. The Times reported that U.S. officials are suspicious that China or Russia may be involved. Secretary of State Mike Pompeo said the precise nature of the injuries suffered has not been determined and promised a "multi-agency response to the unexplained health incidents." Pompeo told the House Foreign Affairs Committee last month that the symptoms being reported in China were "entirely consistent with the medical indications that have taken place to Americans working in Cuba." Last October, the State Department ordered non-essential embassy personnel and the families of all staff to leave Havana, arguing the U.S. could not protect them from unexplained illnesses that have harmed at least 24 Americans. Symptoms sounds, and sensations reportedly varied dramatically from person to person. Some have permanent hearing loss or concussions, while others suffered nausea, headaches and earringing. Some were struggling with concentration or common word recall; the Associated Press has reported [1].

\section{Materials and Methods}

Exposure to infrasound has been demonstrated to affects recipients with symptoms including fear, sorrow, depression, anxiety, nausea, chest pressure and hallucination. It can cause objects to move through vibration and the body's internal organs can be affected. The term infrasonic applied to sound refers to sound waves below the frequencies of audible sound. Nominally includes frequencies under $20 \mathrm{~Hz}$. Sources of infrasound in nature includes volcanoes, avalanches, earthquakes and meteorites. The healthy human ear can hear frequencies ranging from $20 \mathrm{~Hz}$ to $20,000 \mathrm{~Hz}$. Over time, the hair-like stereocilia may get damaged or broken. If enough of them are damaged, hearing loss results. The high frequency area of the cochlea is often damaged by loud sound. Infrasound is sound which extends below the range of human hearing (from $20 \mathrm{~Hz}$ to $0.001 \mathrm{~Hz}$ ), and it emitates from many natural and man-made sources. For example, some animals, such as whales, elephants and giraffes communicate using infrasound over long distances.

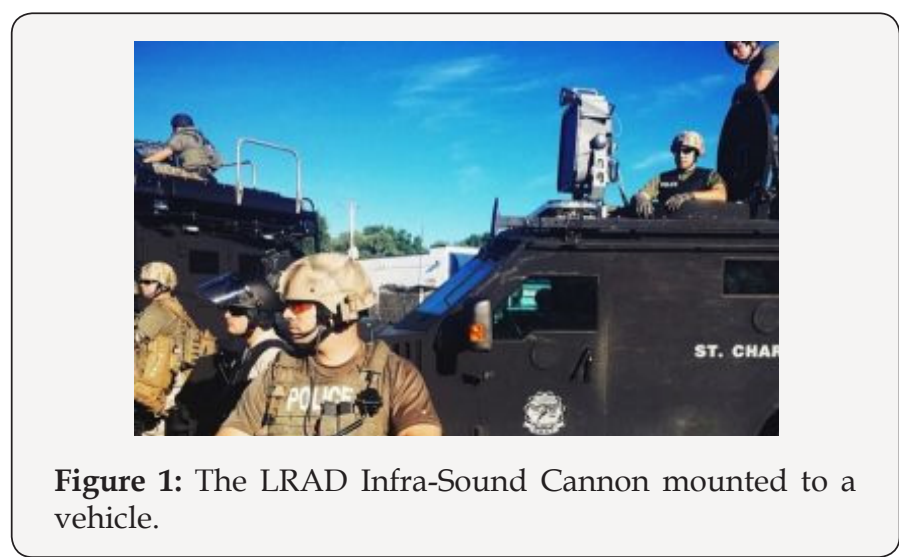


Sonic and ultrasonic weapons (USW) are weapons of various types that use sound to injure, incapacitate, or kill a target. New personal communications show that infrasound can cause trough vibrations, resonance frequency about $7 \mathrm{~Hz}$ with internal organs of humans cause also cancer, such as colorectal cancer, pancreatic cancer, etc. [2-4] Some of these weapons have been described as sonic bullets, sonic grenades, sonic mines, or sonic cannons. Some USWs make a focused beam of sound or ultrasound, some made an area field of sound (Figure 1).

As an example of used sonic weapon we can use The LRAD Sound Cannon as an acoustic weapon and communication device. Developed by the LRAD Corporation to broadcast messages and pain-inducing deterrent tones over long distances. LRAD devices come in various iterations that produce varying degrees of sound. They can be mounted to a vehicle or handheld. Protests in Fergusson, Missouri have reached a terrifying fever pitch, and the ludicrously armed Fersguson Police Department is bringing all its crowd-control weapons to bear, tear gas, stun grenades, rubber bullets. One of the most controversial of those is the LRAD Sound Cannon. The device produces a sound that can be directed in a beam up to 30-degress wide, and the military-grade LRAD 2000X can transmit voice commands at up to $162 \mathrm{~dB}$ up to 5.5 miles away. The LRAD Corporation says that anyone within a 100 meters of the device's sound path will experience an extreme pain. The version generally utilized by Police Departments (the LRAD 500X) is designed to communicate at up to 2000 meters during ideal conditions. In a typical outdoor environment, the device can be heard for 650 meters. The 500X is also capable of short bursts of directed sound that cause headaches in anyone within a 300-meter range. Anyone within 15 meters of the device's audio path can experience permanent hearing loss. LRAD claims the device is not a weapon, but a directed-sound communication device. The U.S. State Department has introduced a gaggle of diplomats house from Guangzhou, China, over worry they had been affected by a mysterious illness that resembles a mind harm and has already affected U.S. group of workers in Cuba, a spokeswoman mentioned. After confirming one executive worker had "suffered a medical incident" in the southern Chinese town, the dept deployed a staff to display screen staff and members of the family at its consulate there, spokeswoman Heather Nauert mentioned in a remark on Wednesday. "As a result of the screening process so far, the department has sent a number of individuals for further evaluation and a comprehensive assessment of their symptoms and findings in the United States," Nauert mentioned [2].

"Medical professionals will continue to conduct full evaluations to determine the cause of the reported symptoms and whether the findings are consistent with those noted in previously affected government personnel or possibly completely unrelated," she mentioned. The New York Times reported that the State Department had evacuated noless than two Americans who fell sick after listening to bizarre noises in China. Chinese Foreign Ministry spokeswoman
Hua Chunying mentioned on Thursday that so far as she was once mindful, the federal government had no longer had any formal conversation with U.S. officers on any new circumstances, and that it had investigated a preliminary incident. "At present, there's been no discovery of clues or the reason causing the situation the United States mentioned," Hua instructed an ordinary information briefing in Beijing, including that China secure diplomats in step with global conference. "If there's really a problem then the U.S. side can directly contact the Chinese side and communicate, and China will continue to conscientiously investigate and coordinate with a responsible attitude," Hua mentioned. Four American individuals of group of workers on the U.S. consulate in Guangzhou referred Reuters to the Beijing embassy press place of business when requested in regard to the state of affairs. A U.S. executive authentic there reiterated that there has been just one showed case in China, introduced closing month, and the State Department was once providing screening to somebody in the U.S. embassy or consulates in China who asked it. In addition to the Beijing embassy and Guangzhou consulate, the United States operates consulates in the mainland Chinese towns of Chengdu, Shanghai, Shenyang and Wuhan. Last year, 24 U.S. executive staff and members of the family in Cuba displayed the indicators, which have been very similar to the ones associated with concussion and delicate stressful mind harm, in step with the State Department. The sicknesses a number of the American diplomats stationed in Havana heightened pressure between the previous Cold War foes. Secretary of State Mike Pompeo launched a remark on Tuesday pronouncing the dept established a role power closing month "to direct a multi-agency response to the unexplained health incidents". "The precise nature of the injuries suffered by the affected personnel, and whether a common cause exists for all cases, has not yet been established," Pompeo mentioned. Source hyperlink

\section{Developing A New Class of Weapons}

Allan H. Frey, at his home outside Washington. In 1960, he stumbled on an acoustic effect of microwaves that was eventually named after him. Microwaves are ubiquitous in modern life. The short radio waves power radars, cook foods, relay messages and link cellphones to antenna towers. They're a form of electromagnetic radiation on the same spectrum as light and X-rays, only at the opposite end. While radio broadcasting can employ waves a mile or more in length, microwaves range in size from roughly a foot to a tiny fraction of an inch. They're seen as harmless in such everyday uses as microwaving foods. But their diminutive size also enables tight focusing, as when dish antennas turn disorganized rays into concentrated beams. The dimensions of the human head, scientists say, make it a fairly good antenna for picking up microwave signals. Mr. Frey, a biologist, said he stumbled on the acoustic effect in 1960 while working for General Electric's Advanced Electronics Center at Cornell University. A man who measured radar signals at a nearby G.E. facility came up to him at a meeting and confided that he could hear the beam's pulses - zip, zip, zip. Intrigued, Mr. Frey traveled 
to the man's workplace in Syracuse and positioned himself in a radar beam. "Lo," he recalled, "I could hear it, too."

Mr. Frey's resulting papers - reporting that even deaf people could hear the false sounds - founded a new field of study on radiation's neural impacts. Mr. Frey's first paper, in 1961, reported that power densities 160 times lower than "the standard maximum safe level for continuous exposure" could induce the sonic delusions. His second paper, in 1962, pinpointed the brain's receptor site as the temporal lobes, which extend beneath the temples. Each lobe bears a small region - the auditory cortex - that processes nerve signals from the outer and inner ears. Investigators raced to confirm and extend Mr. Frey's findings. At first they named the phenomenon after him, but eventually called it the microwave auditory effect and, in time, more generally, radio-frequency hearing. The Soviets took notice. Not long after his initial discoveries, Mr. Frey said, he was invited by the Soviet Academy of Sciences to visit and lecture. Toward the end, in a surprise, he was taken outside Moscow to a military base surrounded by armed guards and barbed-wire fences. "They had me visiting the various labs and discussing the problems," including the neural impacts of microwaves, Mr. Frey recalled. "I got an inside look at their classified program. "Moscow was so intrigued by the prospect of mind control that it adopted a special terminology for the overall class of envisioned arms, calling them psychophysical and psychotronic. Soviet research on microwaves for "internal sound perception," the Defense Intelligence Agency warned in 1976, showed great promise for "disrupting the behavior patterns of military or diplomatic personnel." Furtively, globally, the threat grew. The National Security Agency gave Mark S. Zaid, a Washington lawyer who routinely gets security clearances to discuss classified matters, a statement on how a foreign power built a weapon "designed to bathe a target's living quarters in microwaves, causing numerous physical effects, including a damaged nervous system. " Mr. Zaid said a N.S.A. client of his who traveled there watched in disbelief as his nervous system later unraveled, starting with control of his fingers.

The high-pitched chirping that diplomats heard while working at the Consulate General of the United States in Guangzhou, China, might be explained by a phenomenon known as the Frey effect radio-frequency hearing. Washington, too, foresaw new kinds of arms. The lead inventor said the research team had "experimentally demonstrated" that the "signal is intelligible." As for the invention's uses, an Air Force disclosure form listed the first application as "Psychological Warfare." The Navy sought to paralyze. The Frey effect was to induce sounds powerful enough to cause painful discomfort and, if needed, leave targets unable to move. The weapon, the Navy noted, would have a "low probability of fatalities or permanent injuries. " In a twist, the 2003 contract was awarded to microwave experts who had emigrated to the United States from Russia and Ukraine. It is unknown if Washington deploys such arms. But the Pentagon built a related weapon known as the Active Denial System, hailing it in a video. It fires an invisible beam meant to deter mobs and attackers with fiery sensations. Russia, China and many
European states are seen as having the know-how to make basic microwave weapons that can debilitate, sow noise or even kill. Advanced powers, experts say, might accomplish more nuanced aims such as beaming spoken words into people's heads. Only intelligence agencies know which nations actually possess and use such unfamiliar arms. The basic weapon might look like a satellite dish. In theory, such a device might be hand-held or mounted in a van, car, boat or helicopter. Microwave arms are seen as typically working over relatively short distances - across the length of a few rooms or blocks. High-powered ones might be able to fire beams across several football fields, or even for several miles.

Vladimir Putin, as Russia's president and prime minister, sought to recover the economic, political and strategic clout that the Soviets had lost. In December 2000, months after the start of his first presidential term, Mr. Putin flew to the island nation. It was the first visit by a Soviet or Russian leader since the Cold War. He also sought to resurrect Soviet work on psychoactive arms. In 2012, he declared that Russia would pursue "new instruments for achieving political and strategic goals," including psychophysical weapons.

\section{Discussion}

The LRAD device has been used on several occasions against activists in the USA. The first documented use was in Pittsburgh during the G20 Summit in 2009. The LRAD infra-sound device has potentially long-term effects, including permanent hearing loss and carcinogenesis. (4) Human discomfort starts when sound hits $120 \mathrm{~dB}$, well below the LRAD's threshold. Permanent hearing loss begins at $130 \mathrm{~dB}$, and if the device is turned up to $140 \mathrm{~dB}$, anyone within its path would not only suffer hearing loss, but also lose their balance, and be unable to move out of the path of the audio $[3,4]$. LRAD systems are deployed at airports to sonically deter birds from residing in the pats of aircrafts. The bio-acoustic deterrent helps minimize bird strikes. It means that this device is available for military, police, secret services and also for agricultural companies to sonically deter birds, (in Slovakia reportedly suspected: Rudolf Ertinger with AT Dunaj Dubnik, Slovakia, and his supporter Tomas Pinke, their cars: NZ 123 ER, NZ 810 GK, TN 181 EB, NZ 708 FY, NZ 702 EG), etc.

From the above information it follows that the similar bioacoustic deterrents may have been developed also in other countries, first of all in other powers, such as Russia, China, India. Reportedly, above mentioned bio-acoustic deterrents may use also the Russian-based organized crime (RBOC), and also in different local groups of organized crime in V 4 countries. As it was published in Western media, Russian ambassadors keep dying in mysterious ways. For example, former Russian ambassador to the United Nations, Vitaly Churkin, who died in February 2017 in New York. The US State Department asked the New York medical examiner's office to not release his autopsy. Reportedly, seven Russian ambassadors have died in mysterious ways over the last two years. What's concerning here is that Russia, according to Richard Walton, Scotland Yard's former counter-terror commander, is skilled it is 
disguising, probably by using biological (including bio-acoustic deterrents) or chemical agents that leave no trace. There are simply a lot of really weird coincidences in our world, Rolf Mowatt-Larsen, an intelligence expert at the Harvard Kennedy School, told media.

From the official U. S. State Department data is known that already in the year 1978 from the 22 American diplomats working in Moscow had got 18 (!) health problems with their carcinogenesis. This situation has been only worsened further during later decades' development at the field of sonic weapons. Today there are a lot of possibilities for example to use sonic weapons from the space satellites, like is category of Russian ERA-GLONASS satellites, (they can blockade completely the whole electronic system of the terrestrial cars), etc. [5,6] I was working at the Embassy of the Slovak Republic to Russia in Moscow during the years 2002-2006 as the First Secretary and have also some similar problems with Sonic Attacks. In December 2017 I have sent my request to the Ministry of Foreign Affairs of the Slovak Republic (MoFA SR) in Bratislava to make investigation of my case of sonic health problems. The official Human Resources' General Secretary of the MoFA SR Pavol Sýkorčin have sent me several months ago a letter rejecting my request for as minimum financial rehabilitation from suffered damage during my above diplomatic mission in abroad. It can be also understood as a shameful case of Moral Incompetence!!! Recently I hope that the investigation of the Havana-Case in U. S. State Department will prove my experiences. Especially, the AMA's (The America Medical Association) journal JAMA is by my opinion not the best solution for a new types of Sonic Weapons mechanisms investigation. I am also publishing articles in U. S. scientific journals at the field of Biology during several years and I am convinced that the JAMA is too conservative, old-fashioned, out-dated scientific journal. They have only very limited information about new weapon technologies used recently by military and security forces of the modern states. From this reason I am rejecting the JAMA's conclusions in Havana-Case investigation as not enough qualified! We have asked the Permanent Mission of Sweden to the United Nations to introduce a new initiative on illegalization of the Sonic Weapons (Bio-acoustic deterrents) with formulation of a new International Treaty on Prohibition of the use of the Sonic Weapons. They must be prohibited because are causing Carcinogenesis and Death of Humans. We here in my home in Dubnik h. n. 317-318, Slovakia have a new tragic case when one of the neighbors living next-door Tomas Pinke and his son Sebastian reportedly were misused the Bio-acoustic deterrents against Mária Deáková (66) who had in 3 weeks got a carcinogenesis of liver and from this reason has at July 17, 2018 died!

The Traditional Medicine has not enough information and means to heal these new types of health disorders caused by Sonic Weapons. We also propose to update the International Diseases' Register of the WHO with new Diagnosis of Carcinogenesis caused by Sonic Weapons. Today there is ongoing a Secret Sonic Weapons War between big powers, and smaller countries too, first of all at the level of their Military Intelligence, which is one of the leading causes of the World Cancer Epidemic! [4] The problem is that the victims of these secret operations don't know about the dangers of carcinogenesis caused by above Secret Sonic State"! For this reason, I am convinced, that the topic of sonic weapons caused carcinogenesis is also relevant for bigger interest from the circles of the United Nations and the World Health Organization and other similar international organizations. The secret use of Sonic Weapons leading to the Carcinogenesis may become a new diagnosis of Diplomatic Disease in abroad, and means used against Oppositional Politicians, Critical Intellectuals, etc. Moreover, Sonic Weapons can be used also for the influencing of the Foreign Policy of States at the international stage. For example, the health problems of the President of the European Commission Mr. JeanClaude Juncker during the last NATO Summit in Brussels, in July 11.-12., 2018, were probably caused by Sonic Weapons (the body imbalance, etc.). It was maybe done for clear Political Goals of the Disintegration of NATO...I am convinced now that the use of Sonic Weapons will bring a fundamental change in Diplomacy and in the means of International Policy making.

\section{Conclusion}

Diplomats and their families recounted high-pitched sounds in homes and hotel rooms at times intense enough to incapacitate. Long-term, the symptoms included nausea, crushing headaches, fatigue, dizziness, sleep problems and hearing loss. Rex W. Tillerson, who was then the secretary of state, said the embassy's staff had been targeted deliberately. But he refrained from blaming Cuba, and federal officials held out the possibility that a third party may have been responsible. Beatrice A. Golomb, a medical doctor and professor of medicine at the University of California, San Diego, here in a beachside office, argues that microwave strikes can explain the diplomatic ills. In January, the spooky impact of microwaves on the human brain never came up during an open Senate hearing on the Cuba crisis. But in a scientific paper that same month, James C. Lin of the University of Illinois, a leading investigator of the Frey effect, described the diplomatic ills as plausibly arising from microwave beams. Dr. Lin is the editor-in-chief of Bio Electro Magnetics, a peer-reviewed journal that explores the effects of radio waves and electromagnetic fields on living things. In his paper, he said highintensity beams of microwaves could have caused the diplomats to experience not just loud noises but nausea, headaches and vertigo, as well as possible brain-tissue injury. The beams, he added, could be fired covertly, hitting "only the intended target. " In February, ProPublica in a lengthy investigation mentioned that federal investigators were weighing the microwave theory. Separately, it told of an intriguing find. The wife of a member of the embassy staff, it reported, had looked outside her home after hearing the disturbing sounds and seen a van speeding away. A dish antenna could fit easily into a small van.

To date, the most detailed medical case for microwave strikes has been made by Beatrice A. Golomb, a medical doctor and professor of 
medicine at the University of California, San Diego. In a forthcoming paper to be published in October in Neural Computation, a peerreviewed journal of the MIT Press, she lays out potential medical evidence for Cuban microwave strikes. She compared the symptoms of the diplomats in Cuba to those reported for individuals said to be suffering from radio-frequency sickness. The health responses of the two groups, Dr. Golomb wrote, "conform closely." In closing, she argued that "numerous highly specific features" of the diplomatic incidents "fit the hypothesis" of a microwave attack, including the Frey-type production of disturbing sounds. Scientists still disagree over what hit the diplomats. Last month, JAMA ran four letters critical of the March study, some faulting the report for ruling out mass hysteria. But Mr. Zaid, the Washington lawyer, who represents eight of the diplomats and family members, said microwave attacks may have injured his clients. "It's sort of naïve to think this just started now," he said. Globally, he added, covert strikes with the potent beams appear to have been going on for decades.

Francisco Palmieri, a State Department official, was asked during the open Senate hearing if "attacks against U.S. personnel in Cuba" had been raised with Moscow. "That is a very good question," Mr. Palmieri replied. But addressing it, he added, would require "a classified setting." For his part, Mr. Frey says he doubts the case will be solved anytime soon. The novelty of the crisis, its sporadic nature and the foreign setting made it hard for federal investigators to gather clues and draw conclusions, he said, much less file charges.

\section{Acknowledgment}

The author gratefully acknowledges the assistance of Dr. Marta Ballova, Ing. Konrad Balla, Livuska Ballova and Ing. Jozef Balla.

\section{References}

1. Augustinsson KB, Nachmansohn D (1949) Distinction between Acetylcholine-Esterase and Other Choline Ester-splitting Enzymes. Science 110(2847): 98-99.

2. Yu QS, Holloway HW, Luo W, Lahiri DK, Brossi A, et al. (2010) Long-acting anticholinesterases for myasthenia gravis: synthesis and activities of quaternary phenylcarbamates of neostigmine, pyridostigmine and physostigmine. Bioorg Med Chem 18(13): 4687-4693.

3. Beri V, Gupta R (2007) Acetylcholinesterase inhibitors neostigmine and physostigmine inhibit induction of alpha-amylase activity during seed germination in barley, Hordeum vulgare var. Jyoti. Life Sci 80(24-25): 2386-2388.

4. Jonecko A (1963) [On the Inhibition of the Histochemical Acetylcholinesterase Reaction on Motor End-Plates by Injections of Neostigmine and Physostigmine]. Acta Histochem 16:375-381.

5. Kitz RJ, Braswell LM, Ginsburg S (1970) On the question: is acetylcholinesterase an allosteric protein? Mol Pharmacol 6(2): 108121.

6. Seifert SA, Eldefrawi ME (1974) Affinity of myasthenia drugs to acetylcholinesterase and acetylcholine receptor. Biochem Med 10(3): 258-265.
7. Agatonovic-Kustrin S, Kettle C, Morton DW (2018) A molecular approach in drug development for Alzheimer's disease. Biomed Pharmacother 106: 553-565.

8. Sawada H, Oeda T, Kohsaka M, Umemura A, Tomita S, et al. (2018) Early use of donepezil against psychosis and cognitive decline in Parkinson's disease: a randomized controlled trial for 2 years. J Neurol Neurosurg Psychiatry.

9. Paraoanu LE, Layer PG (2008) Acetylcholinesterase in cell adhesion, neurite growth and network formation. FEBS J 275(4): 618-624.

10. Hasin Y, Avidan N, Bercovich D, Korczyn A, Silman I, et al. (2004) A paradigm for single nucleotide polymorphism analysis: the case of the acetylcholinesterase gene. Hum Mutat 24(5): 408-416.

11. Botti SA, Felder CE, Lifson S, Sussman JL, Silman I (1999) A modular treatment of molecular traffic through the active site of cholinesterase. Biophys J 77(5): 2430-2450.

12. Sussman JL, Harel M, Frolow F, Oefner C, Goldman A, et al. (1991) Atomic structure of acetylcholinesterase from Torpedo californica: a prototypic acetylcholine-binding protein. Science 253(5022): 872-879.

13. Silman I, Harel M, Axelsen P, Raves M, Sussman JL (1994) Threedimensional structures of acetylcholinesterase and of its complexes with anticholinesterase agents. Biochem Soc Trans 22(3): 745-749.

14. Sussman JL, Harel M, Silman I (1993) Three-dimensional structure of acetylcholinesterase and of its complexes with anticholinesterase drugs. Chem Biol Interact 87(1-3): 187-197.

15. Radic Z, Gibney G, Kawamoto S, MacPhee-Quigley K, Bongiorno C, et al (1992) Expression of recombinant acetylcholinesterase in a baculovirus system: kinetic properties of glutamate 199 mutants. Biochemistry 31(40): 9760-9767.

16. Ordentlich A, Barak D, Kronman C, Ariel N, Segall Y, et al. (1995) Contribution of aromatic moieties of tyrosine 133 and of the anionic subsite tryptophan 86 to catalytic efficiency and allosteric modulation of acetylcholinesterase. J Biol Chem 270(5): 2082-2091.

17. Ariel N, Ordentlich A, Barak D, Bino T, Velan B, et al. (1998) The 'aromatic patch' of three proximal residues in the human acetylcholinesterase active centre allows for versatile interaction modes with inhibitors. Biochem J 335 (Pt 1): 95-102.

18. Lu SH, Wu JW, Liu HL, Zhao JH, Liu KT, et al. (2011) The discovery of potential acetylcholinesterase inhibitors: a combination of pharmacophore modeling, virtual screening, and molecular docking studies. J Biomed Sci 18: 8.

19. Tiwari R, Mahasenan K, Pavlovicz R, Li C, Tjarks W (2009) Carborane clusters in computational drug design: a comparative docking evaluation using AutoDock, FlexX, Glide, and Surflex. J Chem Inf Model 49(6): 15811589.

20. Avasthi K, Shukla L, Kant R, Ravikumar K (2014) Folded conformations due to arene interactions in dissymmetric and symmetric butylidenelinker models based on pyrazolo[3,4-d]pyrimidine, purine and 7-deazapurine. Acta Crystallogr C Struct Chem 70(Pt 6): 555-561.

21. McGaughey GB, Gagne M, Rappe AK (1998) pi-Stacking interactions. Alive and well in proteins. J Biol Chem 273(25): 15458-15463.

22. Ordentlich A, Barak D, Kronman C, Flashner Y, Leitner M, et al. (1993) Dissection of the human acetylcholinesterase active center determinants of substrate specificity. Identification of residues constituting the anionic site, the hydrophobic site, and the acyl pocket. J Biol Chem 268(23): 17083-17095. 
(C) (P) This work is licensed under Creative

Submission Link: Submit Article

DOI: 10.32474/DDIPIJ.2018.02.000137

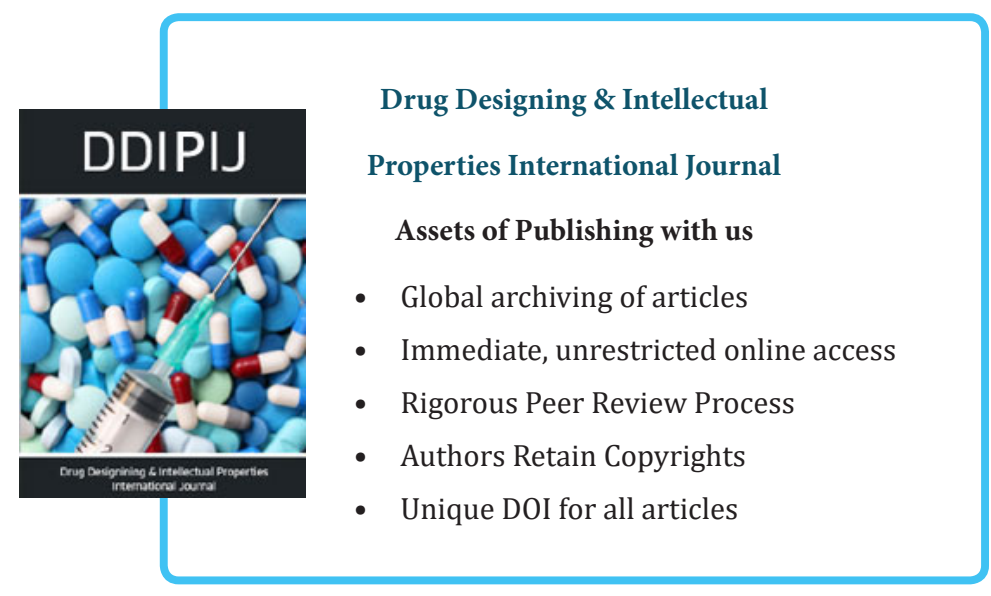

